\title{
Effect of tail fin loss on swimming capability and tail beat frequency of juvenile black carp Mylopharyngodon piceus
}

\author{
Lu Cai ${ }^{1,2,3}$, Jihua Chen ${ }^{3}$, David Johnson ${ }^{2,4}$, Zhiying Tu${ }^{1}$, Yingping Huang ${ }^{1,3, *}$ \\ ${ }^{1}$ Engineering Research Center of Eco-environment in Three Gorges Reservoir Region, Ministry of Education, \\ China Three Gorges University, Yichang 443002, PR China \\ ${ }^{2}$ Key Laboratory of Ecological Impacts of Hydraulic-Projects and Restoration of Aquatic Ecosystem of Ministry of Water \\ Resources, Institute of Hydroecology, Ministry of Water Resources and Chinese Academy of Sciences, Wuhan 430079, PR China \\ ${ }^{3}$ College of Hydraulic \& Environmental Engineering, China Three Gorges University, Yichang 443002, PR China \\ ${ }^{4}$ School of Natural Sciences and Mathematics, Ferrum College, Ferrum, VA 24088, USA
}

\begin{abstract}
Fin clipping is a common practice in fisheries management, and hatchery fish are often marked this way. In the wild, the tail (caudal) fin may be damaged or lost to predation or disease. Because the tail fin is important to fish swimming behavior and ability, this study was designed to examine the effects of partial and complete loss of the tail fin on the swimming ability of juvenile black carp Mylopharyngodon piceus. Swimming speed and tail beat frequency were measured for 3 groups (intact tail fin, partial tail fin, no tail fin) using a stepped velocity test conducted in a fish respirometer. We found that critical swimming speed $\left(\mathrm{U}_{\text {crit }}\right)$ and burst speed $\left(\mathrm{U}_{\text {burst }}\right)$ decreased slightly in the partial fin group and significantly in the no fin group. In the group with no tail fin, $U_{\text {burt }}$ decreased more than $U_{\text {crit, }}$ clearly reducing the ability to avoid predators. Moreover, mean tail beat frequency $\left(\mathrm{TBF}_{\text {mean }}\right), \mathrm{U}_{\text {crit }}$ and $\mathrm{U}_{\text {burst }}$ all decreased slightly in the partial fin group and significantly in the no fin group. A decrease in tail beat force and TBF both reduce swimming capability. These findings contribute to developing our understanding of the relationship between fish tail fins and swimming.
\end{abstract}

KEY WORDS: Swimming performance $\cdot$ Tail fin loss $\cdot$ Critical swimming speed $\cdot$ Burst speed Tail beat frequency

\section{INTRODUCTION}

Body shape in fishes evolved with their adaptations to different environmental conditions (Langerhans et al. 2004) and, because natural flow velocities vary widely, fish adapted to different flow regimes. Generally, fish that have adapted to high flow velocities are strong swimmers and have a streamlined body shape (Langerhans et al. 2007, Yan et al. 2013).

In the laboratory, swimming capability is frequently measured using a stepped velocity test (Brett 1964). Among the stepped velocity tests, the critical swimming speed ( $\left.\mathrm{U}_{\text {crit }}\right)$ protocol is used to evaluate pro-

*Corresponding author: chem_ctgu@126.com longed swimming capability. Although this approach may introduce bias as fatigue accumulates through the time steps, it is useful for comparing the relative influence of factors that affect fish swimming capability. Fish use burst swimming when they pursue prey, flee from predators or encounter high-velocity currents. Although endurance is low at burst speed $\left(\mathrm{U}_{\text {burst }}\right)$, burst swimming is important for survival. The lowest flow velocity that induces continuous fish motion is termed the induced flow velocity $\left(\mathrm{U}_{\text {ind }}\right)$. This parameter is useful for fish passage design because fish maintain their orientation more easily when flow velocity is higher than $U_{\text {ind }}$ (Cai et al. 2018).

() The authors 2020. Open Access under Creative Commons by Attribution Licence. Use, distribution and reproduction are unrestricted. Authors and original publication must be credited. 
Fin clipping is a common practice in fisheries management, and hatchery fish are often marked by clipping adipose fins and, less frequently, pelvic fins (Hansen 1988, Vander Haegen et al. 2005). The tail (caudal) fin is important, both for locomotion and changing direction (Ohlberger et al. 2007, Handegard et al. 2009), and the sizes and shapes of tail fins vary across species. Tail beat frequency (TBF) is an important index of fish swimming behavior and its correlation with swimming speed is near linear (Hunter \& Zweifel 1971, Webb 1975, Beamish 1978). Fish species differ in tail fin type (size and hardness), which affects swimming capability (Plaut 2001). The tail fin may be damaged or lost to predation or disease, and it would thus be useful to investigate the effect of such damage or loss on swimming performance.

The black carp Mylopharyngodon piceus is a cyprinid species native to China and eastern Russia. Preying on snails, shellfish, shrimp and insects, black carp provide biological control of aquatic pests (Ben-Ami \& Heller 2001) and survive well in freshwaters if predators, such as yellowcheek Elopichthys bambu$s a$, do not find them. Black carp have been transported, accidentally and/or intentionally, to many countries and are considered an invasive species in certain countries where they threaten native fish.

Here, we tested the swimming performance of black carp by measuring $\mathrm{U}_{\text {crit }}, \mathrm{U}_{\text {burst }}, \mathrm{U}_{\text {ind }}$ and TBF. The effect of tail fin loss on swimming capability was also investigated. The results add to our knowledge of the relationship between fish swimming speed and tail beat.

\section{MATERIALS AND METHODS}

\subsection{Ethics statement}

This study was conducted in strict accordance with the laws governing animal experimentation in China. The protocol was approved by the China Three Gorges University. All efforts were made to minimize suffering.

\subsection{Test fish}

Juvenile black carp (standard length $=11.4 \pm 1.0 \mathrm{~cm}$, mass $=23.9 \pm 6.1 \mathrm{~g} ; \mathrm{SD}, \mathrm{n}=60$ ), were obtained from an aquaculture farm in Tongren, China $\left(27^{\circ} 94^{\prime} \mathrm{N}\right.$, $108^{\circ} 23^{\prime} \mathrm{E}$ ). The test fish were maintained in tanks of river water $\left(20.2-23.4^{\circ} \mathrm{C}\right)$ and fed to satiation daily at 07:00 and 16:00 $\mathrm{h}$ with a compound feed (crude protein $\geq 45 \%$, fat $\geq 10 \%$, crude fiber $\geq 3 \%$ and ash $\geq 17 \%$ ).

\subsection{Equipment}

Based on a study on fish swimming and coasting distance by Müller et al. (2000), Peake \& Farrell (2006) suggested that the swim chamber length should be $>2.1$ body lengths (bl) to avoid the effects of respirometer confinement. Cai et al. (2018) suggested the minimum swim chamber length should be $>5 \mathrm{bl}$, based on measurements of swimming speeds of fish with different body lengths. In the present study, the swim chamber length was $70 \mathrm{~cm}(4.9-7.7 \mathrm{bl})$. Fish were tested in a modified Brett-type swimming respirometer with a volume of 951 and a 281 rectangular swim chamber $(70 \mathrm{~cm} \times 20 \mathrm{~cm} \times 20 \mathrm{~cm})$. A flow rectifier (honeycomb shape) maintained nearly uniform flow in the chamber, and a grid at the end of the chamber prevented fish from being swept away (Cai et al. 2018). Test fish had a maximum crosssectional area $<10 \%$ of the chamber cross-section, and it was assumed that fish swimming speed equaled flow velocity (Bell \& Terhune 1970). Flow velocity was measured by a propeller-type flow velocity meter (LGY-II). In the respirometer, dissolved oxygen ranged from 7.61 to $8.35 \mathrm{mg} \mathrm{l}^{-1}$ and water temperature ranged from 20.2 to $23.4^{\circ} \mathrm{C}$, as measured with a multi-sensor probe (Hach HQ30d). A video camera (Hikvision CS-C6TC-32WFR) was placed over the respirometer to record tail beat.

\subsection{Test protocol}

Stepped velocity tests were carried out to measure $U_{\text {crit }}, U_{\text {burst }}, U_{\text {ind }}$ and TBF. Sixty healthy fish with intact fins and squamae were selected randomly for testing and were randomly placed into 3 groups of 20 individuals. Group 1 was not treated (intact fin). In Group 2, the tail fin was partially removed (fin clipped posterior to fork), and in Group 3, the tail fin was completely removed (Fig. 1). Thirty fish (10 from each group) were tested for $U_{\text {crit }}$ and TBF (Expt 1) and the other thirty fish were tested for $\mathrm{U}_{\text {burst }}$ and $\mathrm{U}_{\text {ind }}$ (Expt 2).

\subsubsection{Expt 1}

Thirty fish were tested individually. Fish body length and mass were measured, and each fish was allowed to acclimate to experimental conditions at $0.05 \mathrm{~m} \mathrm{~s}^{-1}\left(0.35-0.50 \mathrm{bl} \mathrm{s}^{-1}\right)$ for $2 \mathrm{~h}$. Flow velocity, initially at $1.0 \mathrm{bl} \mathrm{s}^{-1}$, was increased by $1.0 \mathrm{bl} \mathrm{s}^{-1}$ at 20 min intervals (Brett 1964, Tierney 2011). When the 


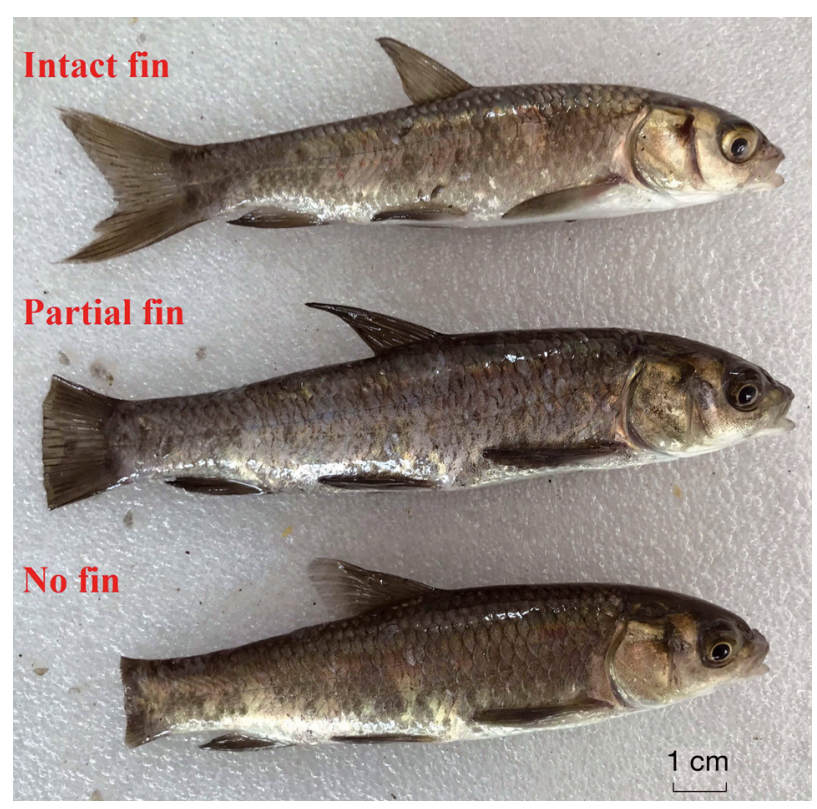

Fig. 1. Representative juvenile black carp from the 3 treatment groups (intact fin, partial fin and no fin)

fish ceased swimming, the flow velocity was decreased, the swim chamber was rapped to encourage swimming, and the test was resumed if the fish continued swimming. A fish was regarded as exhausted when it did not resume swimming and rested against the wire grid for $10 \mathrm{~s}$. The $\mathrm{U}_{\text {crit }}$ was calculated using Eq. (1) in Section 2.5. Tail beat frequency was measured using the digital recordings to obtain $\mathrm{TBF}_{\max }$ and $\mathrm{TBF}_{\text {mean }}\left(\right.$ beats $\mathrm{s}^{-1}$ ).

\subsubsection{Expt 2}

Thirty fish were tested individually. Fish body length and mass were measured, and each fish was allowed to acclimate to experimental conditions at $0.05 \mathrm{~m} \mathrm{~s}^{-1}$ for $2 \mathrm{~h}$. At that velocity, the fish remained nearly motionless along the flow direction. The flow velocity was then increased by $0.01 \mathrm{~m} \mathrm{~s}^{-1}$ at $5 \mathrm{~s}$ intervals and, when the fish began actively swimming, the flow velocity was reported as $U_{\text {ind }}$ (Cai et al. 2018). Flow velocity was then adjusted to $1.0 \mathrm{bl} \mathrm{s}^{-1}$ and increased by $1.0 \mathrm{bl} \mathrm{s}^{-1}$ at $1 \mathrm{~min}$ intervals (Tierney 2011, Wang et al. 2017). When the fish ceased swimming, the flow velocity was decreased, the swim chamber was rapped to encourage swimming, and the test was resumed if the fish continued swimming. A fish was regarded as exhausted when it did not resume swimming and rested against the wire grid for $10 \mathrm{~s}$. $\mathrm{U}_{\text {burst }}$ was calculated using Eq. (1).

\subsection{Data analyses}

$\mathrm{U}_{\text {crit }}$ (and $\mathrm{U}_{\text {burst }}$ ) were calculated using Eq. (1) (Brett 1964, Dai \& Suski 2019):

$$
\mathrm{U}_{\text {crit }}=\mathrm{U}_{i-1}+\left(t_{i} / \Delta t\right) \times \Delta \mathrm{U}
$$

where $i$ is the increment number in stepped velocity tests, $\mathrm{U}_{i-1}\left(\mathrm{bl} \mathrm{s}^{-1}\right)$ is the velocity during the last complete time increment, $\Delta \mathrm{U}\left(\mathrm{bl} \mathrm{s}^{-1}\right)$ is the velocity step, $\Delta t(\mathrm{~s})$ is the time step, and $t_{i}(\mathrm{~s})$ is the time elapsed at fatigue during the last (incomplete) time step.

The data were analyzed using Origin 9.0 (OriginLab), and parameter values are reported as mean \pm $\mathrm{SD}$. Data on fish body length, mass, $\mathrm{U}_{\text {crit, }} \mathrm{U}_{\text {burst }}, \mathrm{U}_{\text {ind, }}$ $\mathrm{TBF}_{\text {max }}$ and $\mathrm{TBF}_{\text {mean }}$ did not significantly deviate from normality, according to a Lilliefors test ( $p>$ 0.05). Homogeneity of variance among parameters was tested using Levene's test and differences in variance were not significant ( $p>0.05)$. ANOVA was used to test differences among mean values, and $a$ posteriori pairwise comparisons were made using a Tukey test.

\section{RESULTS}

In Expts 1 and 2, there were no significant differences between the 3 treatment groups with respect to body length and mass (all $p>0.05$ ). The results for $\mathrm{U}_{\text {crit, }} \mathrm{U}_{\text {burst }}, \mathrm{U}_{\text {ind, }}, \mathrm{TBF}_{\text {max }}$ and $\mathrm{TBF}_{\text {mean }}$ are presented in Figs. 2-5. Based on 1-way ANOVA, there were significant effects of experimental treatments on $\mathrm{U}_{\text {crit }}$ (bl s${ }^{-1}$ and $\mathrm{m} \mathrm{s}^{-1}, \mathrm{p}=0.016$ and 0.011), $\mathrm{U}_{\text {burst }}\left(\mathrm{bl} \mathrm{s} \mathrm{s}^{-1}\right.$ and $\mathrm{m} \mathrm{s}^{-1}$, both $\mathrm{p}<0.001$ ) and $\mathrm{TBF}_{\text {mean }}$ (beats $\mathrm{s}^{-1}, \mathrm{p}<$

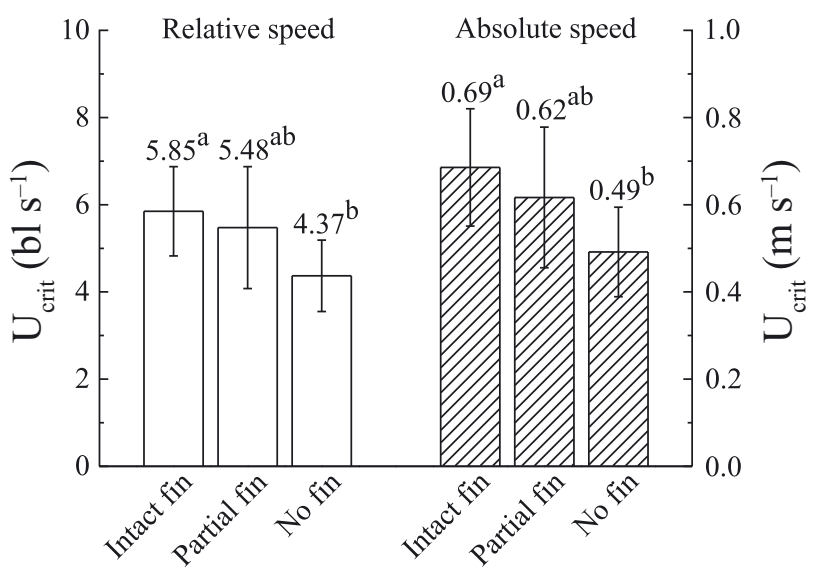

Fig. 2. Variation in the critical swimming speed $\left(\mathrm{U}_{\text {crit }}\right)$ of juvenile black carp (standard length $=11.4 \pm 1.0 \mathrm{~cm}$ ), both relative (body lengths [bl] s${ }^{-1}$ ) and absolute $\left(\mathrm{m} \mathrm{s}^{-1}\right)$, among treatment groups. Error bars are SD. Different letters (a and b) above the columns indicate a significant difference between groups 


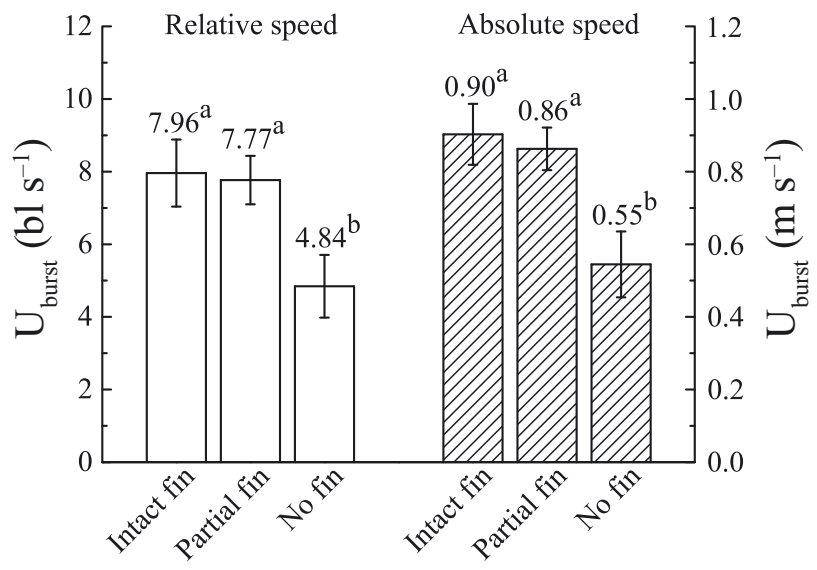

Fig. 3. Variation in the burst speed $\left(\mathrm{U}_{\text {burst }}\right)$ of juvenile black carp; details as in Fig. 2

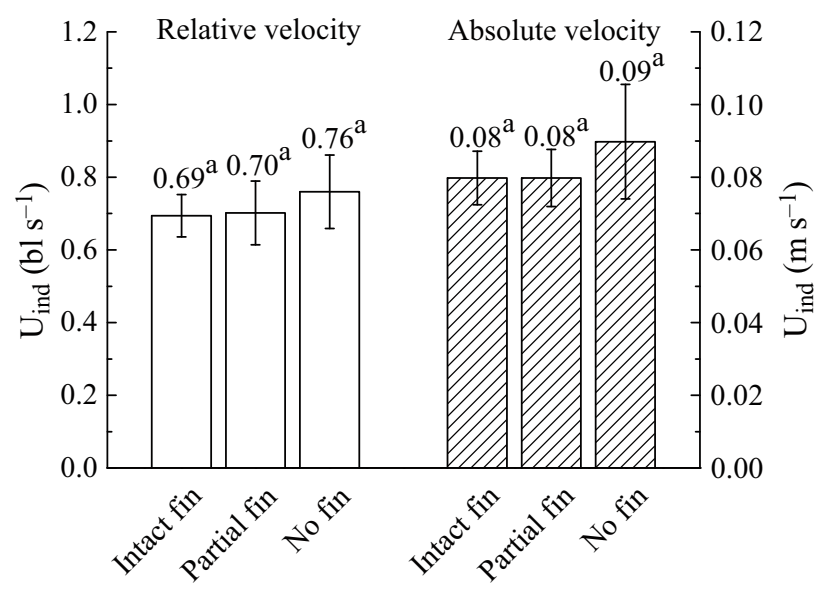

Fig. 4. Variation in the induced flow velocity $\left(\mathrm{U}_{\text {ind }}\right)$ of juvenile black carp; details as in Fig. 2

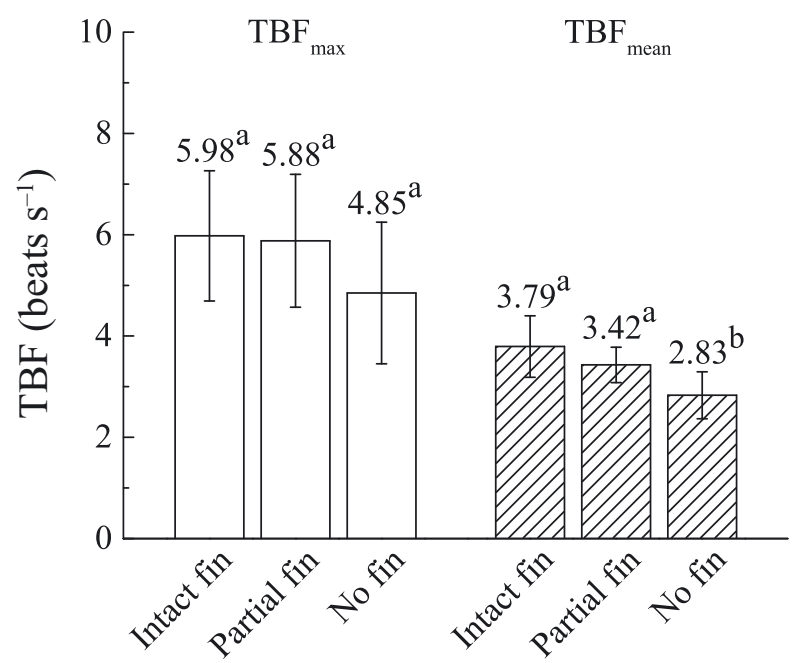

Fig. 5. Variation in the tail beat frequency $\left(\mathrm{TBF}_{\max }\right.$ and $\mathrm{TBF}_{\text {mean }}$, beats $\mathrm{s}^{-1}$ ) of juvenile black carp (standard length = $11.4 \pm 1.0 \mathrm{~cm}$ ) among treatment groups. Different letters (a and b) above the columns indicate a significant difference between groups
0.001), but effect was not significant on $\mathrm{U}_{\text {ind }}\left(\mathrm{bl} \mathrm{s} \mathrm{s}^{-1}\right.$ and $\mathrm{m} \mathrm{s}^{-1}, \mathrm{p}=0.179$ and 0.229 ) or $\mathrm{TBF}_{\max }$ (beats $\mathrm{s}^{-1}$, $\mathrm{p}=0.130$ ). Based on comparison of means (Tukey test), $\mathrm{U}_{\text {crit }}, \mathrm{U}_{\text {burst }}$ and $\mathrm{TBF}_{\text {mean }}$ were significantly lower in the no fin groups than in the intact fin groups (all $\mathrm{p}<0.05)$, but $U_{\text {crit }}, U_{\text {burst }}$ and $\mathrm{TBF}_{\text {mean }}$ in the partial fin groups were not significantly lower than in the intact fin groups (all $p>0.05$ ). Thus, complete loss of the tail fin had considerably more effect on swimming performance than partial loss, and the effect of tail fin loss was significant on $\mathrm{U}_{\text {crit, }} \mathrm{U}_{\text {burst }}$ and $\mathrm{TBF}_{\text {mean, }}$ but not on $\mathrm{U}_{\text {ind }}$ and $\mathrm{TBF}_{\max }$.

\section{DISCUSSION}

\subsection{Critical swimming speed, $U_{\text {crit }}$}

The tail fin is important to fish swimming capability (Hunter \& Zweifel 1971, Webb 1975, Beamish 1978). Fin loss reduces swimming capability (Plaut 2001), but the reduction varies significantly among species (Fu et al. 2013). $U_{\text {crit, }}$ a measure of prolonged swimming capability, can be attained primarily by aerobic metabolism (Brett 1964, Milligan 1996). In this study, the decrease in $U_{\text {crit }}$ was not significant for the partial fin group but was significant for the no fin group (Fig. 2). It appears likely that the decrease in $\mathrm{U}_{\text {crit }}$ would also be significant in the partial fin group if the sample size was larger.

The black carp Mylopharyngodon piceus is 1 of 4 common domestic fishes of China; the other 3 species are grass carp Ctenopharyngodon idella, silver carp Hypophthalmichthys molitrix and bighead carp Aristichthys (Hypophthalmichthys) nobilis. In China, all 4 species inhabit the same rivers and lakes and all are important commercially. $U_{\text {crit }}$ values for juveniles of the other 3 species are shown in Table 1. The $U_{\text {crit }}$ of $M$. piceus is higher than that of $H$. molitrix, but lower than that of $C$. idellus and A. nobilis. Black carp primarily inhabit the middle to bottom waters and forage for snails, shellfish, shrimp and insects. They are not considered to be very active fish, consistent with the relatively low swimming capability found in this study.

\subsection{Burst speed, $U_{\text {burst }}$}

$\mathrm{U}_{\text {burst }}$ is an estimate of the speed that can be attained with the contribution of anaerobic metabolism, which leads to lactic acid accumulation (Brett 1964, Dominy 1971). Compared with the intact fin group, $U_{\text {burst }}$ decreased slightly in the partial fin 
Table 1. Critical swimming speed ( $\mathrm{U}_{\text {crit }}$ ) of 4 common domestic fishes in China; bl: body length; Temp: temperature; $\mathrm{n}$ : number of fish. Data are reported as mean $\pm \mathrm{SD}$

\begin{tabular}{|lcccccc|}
\hline Species & $\mathrm{bl}, \mathrm{m}$ & $\mathrm{Temp},{ }^{\circ} \mathrm{C}$ & $\mathrm{n}$ & $\mathrm{U}_{\text {crit, }} \mathrm{bl} \mathrm{s}^{-1}$ & $\mathrm{U}_{\text {crit, }} \mathrm{m} \mathrm{s}^{-1}$ & Reference \\
\hline Mylopharyngodon piceus & $0.117 \pm 0.012$ & 22 & 10 & $5.9 \pm 1.0$ & $0.69 \pm 0.13$ & This study \\
& $0.079 \pm 0.003$ & 25 & 7 & $\sim 5.6$ & $0.44 \pm 0.03$ & Yan et al. (2013) \\
Ctenopharyngodon idella & $0.112 \pm 0.007$ & 20 & 16 & $9.4 \pm 1.3$ & $1.05 \pm 0.15$ & Cai et al. (2014) \\
& $0.055 \pm 0.003$ & 25 & 8 & $\sim 7.8$ & $0.43 \pm 0.04$ & Yan et al. (2013) \\
Hypophthalmichthys molitrix & $0.130 \pm 0.005$ & 20 & 20 & $5.0 \pm 0.6$ & $0.65 \pm 0.07$ & Ke et al. (2019) \\
& $0.096 \pm 0.006$ & 20 & 20 & $5.7 \pm 0.8$ & $0.55 \pm 0.07$ & Ke et al. (2019) \\
& $\sim 0.096$ & 21 & 30 & $\sim 4.6$ & $\sim 0.44$ & Shi et al. (2014) \\
Aristichthys nobilis & $0.075 \pm 0.002$ & 25 & 8 & $\sim 7.1$ & $0.53 \pm 0.03$ & Yan et al. (2013) \\
& $\sim 0.196$ & $22-25$ & 14 & $\sim 5.8$ & $\sim 0.97$ & Yuan et al. (2014) \\
& $\sim 0.118$ & 25 & 10 & $6.8 \pm 0.3$ & $0.80 \pm 0.04$ & Yuan et al. (2019) \\
& $0.069 \pm 0.002$ & 25 & 8 & $\sim 6.5$ & $0.45 \pm 0.07$ & Yan et al. (2013) \\
\hline
\end{tabular}

group and significantly in the no fin group (Fig. 3), similar to the results for prolonged swimming capability ( $\mathrm{U}_{\text {crit }}$ ). It has been speculated that swimming propulsion by the caudal fin is mainly provided by the front half of the tail because the soft, flexible back half can generate only a weak propulsive force (Tangorra et al. 2010). It is also possible that swimming behavior can be altered to partially offset the loss of the caudal fin, and the degree of compensation depends on the amount of tail that is missing.

The $\mathrm{U}_{\text {crit }}$ decreased by $\sim 25 \%$ from the intact fin group to the no fin group (Fig. 2), and $\mathrm{U}_{\text {burst }}$ decreased by $\sim 40 \%$ (Fig. 3). The large decrease in burst speed has serious consequences for avoiding predators such as Elopichthys bambusa. Fish missing the tail fin are also less able to pass obstructions and control structures, such as road crossings, that generate high-velocity flows, which also negatively affects dispersal and migration.

\subsection{Induced flow velocity, $U_{\text {ind }}$}

Holding their position in a current is innate behavior for fish. Fish sense water motion by means of the lateral line organ and adjust swimming as needed to counter the current (Arnold 1974, Montgomery \& Macdonald 1987). The $U_{\text {ind }}\left(\mathrm{m} \mathrm{s}^{-1}\right)$ increases with body length (Cai et al. 2018). In Fig. 4, the differences in $U_{\text {ind }}$ among the 3 treatment groups was not significant, indicating that the tail fin has little effect on $U_{\text {ind }}$.

\subsection{Tail beat frequency, TBF}

TBF is integral to the kinematics of swimming and is closely related to swimming capability (Webb 1975).
The linear correlation between TBF and U has been verified repeatedly (Videler \& Wardle 1991, Ohlberger et al. 2007, Cai et al. 2013). In the present study, tail fin loss had little effect on the $\mathrm{TBF}_{\max }$ of black carp (Fig. 5), consistent with the findings for the cyprinid Spinibarbus sinensis (Fu et al. 2013) and contrary to the results for common carp Cyprinus carpio and goldfish Carassius auratus, for which $\mathrm{TBF}_{\max }$ increased significantly with tail fin loss (Fu et al. 2013).

$\mathrm{TBF}_{\text {mean }}$ was slightly lower in the partial fin group and significantly lower in the no fin group (Fig. 5), similar to results for $U_{\text {crit }}$ and $U_{\text {burst }}$. Loss of the tail fin lowers thrust (tail beat force) and, when tail beating is ineffective, the lower TBF could be an instinctive response evolved from the need to conserve energy. A large tail fin and small tail fin aspect ratio are advantageous for fish swimming capability (Langerhans et al. 2004, Domenici et al. 2008). With loss of tail fin area, the thrust per tail beat is lower and the kinematics are less efficient. However, thrust is not generated from the tail fin alone, as other fins and the body also generate thrust.

The tail fin has the potential for decreasing muscle activity and conserving energy by exploiting the vortices created by the beating tail (Liao et al. 2003). Fish use a burst-and-coast gait in the $\mathrm{U}_{\text {burst }}$ test and in the higher-velocity steps of the $U_{\text {crit }}$ test. Burst and coast phases generate different vortices, and the drag coefficient is lower during the coast phase (Wu et al. 2007), conserving energy. While partial fin loss does not significantly reduce swimming capability, total loss does significantly decrease swimming capability and increases the energy cost of transport.

The difference between swimming capability between the intact fin and partial fin groups was small (Figs. $2 \& 3$ ). Hence, we speculate that partial fin loss does not significantly affect thrust and vortices. The 
rear half of the tail fin is soft, and thus the beat force is lower and may not have a large effect on the vortices. This speculation could be verified by future studies on particle image velocimetry.

\section{CONCLUSION}

This study provides data on $\mathrm{U}_{\text {crit }}, \mathrm{U}_{\text {burst, }} \mathrm{U}_{\text {ind }}, \mathrm{TBF}_{\max }$ and $\mathrm{TBF}_{\text {mean }}$ of black carp, and the effect of partial and complete tail fin loss on TBF and swimming capability. Differences among $\mathrm{U}_{\text {ind }}$ and $\mathrm{TBF}_{\max }$ in the 3 treatment groups were not significant. $\mathrm{U}_{\text {crit }}$ and $\mathrm{U}_{\text {burst }}$ decreased slightly with partial loss of fin, but decreased significantly with complete loss. Partial, and especially complete loss, of the tail fin resulted in lower beat force and $\mathrm{TBF}_{\text {mean }}$. Further, tail fin loss interrupts the vortices produced by tail beats, lowering the potential for energy conservation during burstand-coast swimming and decreasing $\mathrm{U}_{\text {crit }}$ and $\mathrm{U}_{\text {burst }}$.

Acknowledgements. This work was supported by the Engineering Research Center of Eco-environment in the Three Gorges Reservoir Region, Ministry of Education, China (grant number: KF2019-09) and the National Nature Science Foundation of China (grant numbers: 51609155, 51679126).

\section{LITERATURE CITED}

Arnold GP (1974) Rheotropism in fishes. Biol Rev Camb Philos Soc 49:515-576

Beamish FWH (1978) Swimming capacity. In: Hoar WS, Randall DJ (eds) Fish physiology. Academic Press, New York, NY, p 101-187

Bell WH, Terhune LDB (1970) Water tunnel design for fisheries research. Tech Rep No. 195. Fisheries Research Board of Canada, Ottawa

Ben-Ami F, Heller J (2001) Biological control of aquatic pest snails by the black carp Mylopharyngodon piceus. Biol Control 22:131-138

Brett JR (1964) The respiratory metabolism and swimming performance of young sockeye salmon. J Fish Res Board Can 21:1183-1226

Cai L, Taupier R, Johnson D, Tu Z, Liu G, Huang Y (2013) Swimming capability and swimming behavior of juvenile Acipenser schrenckii. J Exp Zool A Ecol Genet Physiol 319:149-155

Cai L, Fang M, Johnson D, Lin S, Tu Z, Liu G, Huang Y (2014) Interrelationships between feeding, food deprivation and swimming performance in juvenile grass carp. Aquat Biol 20:69-76

Cai L, Katopodis C, Johnson D, Zhang P, Zhao P (2018) Case study: targeting species and applying swimming performance data to fish lift design for the Huangdeng Dam on the upper Mekong River. Ecol Eng 122:32-38

Dai Q, Suski CD (2019) Effects of acclimation temperature on critical thermal limits and swimming performance of the state-endangered bigeye chub Hybopsis amblops. Aquat Biol 28:137-147
Domenici P, Turesson H, Brodersen J, Bronmark C (2008) Predator-induced morphology enhances escape locomotion in crucian carp. Proc R Soc B 275:195-201

*Dominy CL (1971) Changes in blood lactic acid concentrations in alewives (Alosa pseudoharengus) during passage through a pool and weir fishway. J Fish Res Board Can 28:1215-1217

Fu C, Cao ZD, Fu SJ (2013) The effects of caudal fin loss and regeneration on the swimming performance of three cyprinid fish species with different swimming capacities. J Exp Biol 216:3164-3174

*Handegard NO, Pedersen G, Brix O (2009) Estimating tailbeat frequency using split-beam echosounders. ICES J Mar Sci 66:1252-1258

*Hansen LP (1988) Effects of Carlin tagging and fin clipping on survival of Atlantic salmon (Salmo salar L.) released as smolts. Aquaculture 70:391-394

Hunter JR, Zweifel JR (1971) Swimming speed, tail beat frequency, tail beat amplitude and size in jack mackerel, Trachurus symmetricus, and other fishes. Fish Bull 69: 253-266

Ke S, Li Z, Jiang Z, Goerig E, Kynard B, Liu D, Shi X (2019) Effect of a vertical half cylinder on swimming of silver carp, Hypophthalmichthys molitrix: implications for microhabitat restoration and fishway design. River Res Appl 35:436-441

*Langerhans RB, Layman CA, Shokrollahi AM, Dewitt TJ (2004) Predator-driven phenotypic diversification in Gambusia affinis. Evolution 58:2305-2318

* Langerhans RB, Chapman LJ, DeWitt TJ (2007) Complex phenotype-environment associations revealed in an East African cyprinid. J Evol Biol 20:1171-1181

พLiao JC, Beal DN, Lauder GV, Triantafyllou MS (2003) Fish exploiting vortices decrease muscle activity. Science 302: 1566-1569

Milligan CL (1996) Metabolic recovery from exhaustive exercise in rainbow trout. Comp Biochem Physiol A Physiol 113:51-60

Montgomery JC, Macdonald JA (1987) Sensory tuning of lateral line receptors in Antarctic fish to the movements of planktonic prey. Science 235:195-196

Müller UK, Stamhuis EJ, Videler JJ (2000) Hydrodynamics of unsteady fish swimming and the effects of body size: comparing the flow fields of fish larvae and adults. J Exp Biol 203:193-206

Ohlberger J, Staaks G, Hölker F (2007) Estimating the active metabolic rate (AMR) in fish based on tail beat frequency (TBF) and body mass. J Exp Zool A Ecol Genet Physiol 307:296-300

*Peake SJ, Farrell AP (2006) Fatigue is a behavioural response in respirometer-confined smallmouth bass. J Fish Biol 68:1742-1755

* Plaut I (2001) Critical swimming speed: its ecological relevance. Comp Biochem Physiol Part A Mol Integr Physiol 131:41-50

Shi X, Chen Q, Liu D, Huang Y, Zhuang P, Lu B (2014) Juvenile silver carp Hypophthalmichthys molitrix swim faster in closed surface flow than open surface flow. Environ Biol Fishes 97:1411-1416

Tangorra JL, Lauder GV, Hunter IW, Mittal R, Madden PGA, Bozkurttas M (2010) The effect of fin ray flexural rigidity on the propulsive forces generated by a biorobotic fish pectoral fin. J Exp Biol 213:4043-4054

Tierney KB (2011) Swimming performance assessment in fishes. J Vis Exp 51:e2572 
Vander Haegen GE, Blankenship HL, Hoffmann A, Thompson DA (2005) The effect of adipose fin clipping and coded wire tagging on the survival and growth of spring Chinook salmon. N Am J Fish Manag 25:1161-1170

Videler JJ, Wardle CS (1991) Fish swimming stride by stride: speed limits and endurance. Rev Fish Biol Fish 1:23-40

Wang Y, An R, Li Y, Li K (2017) Swimming performance of rock carp Procypris rabaudi and Prenant's schizothoracin Schizothorax prenanti acclimated to total dissolved gas supersaturated water. N Am J Fish Manag 37:1183-1190

Webb PW (1975) Hydrodynamics and energetics of fish propulsion. Bull Fish Res Board Can 190:113-119

Wu G, Yang Y, Zeng L (2007) Kinematics, hydrodynamics and energetic advantages of burst-and-coast swimming

Editorial responsibility: Helmut Segner,

Bern, Switzerland of koi carps (Cyprinus carpio koi). J Exp Biol 210: 2181-2191

* Yan GJ, He XK, Cao ZD, Fu SJ (2013) An interspecific comparison between morphology and swimming performance in cyprinids. J Evol Biol 26:1802-1815

Yuan X, Li LP, Tu ZY, Cai L, Johnson DM, Huang YP (2014) The effect of temperature on fatigue induced changes in the physiology and swimming ability of juvenile Aristichthys nobilis (bighead carp). Acta Hydrobiologica Sinica 38:505-509

พ Yuan X, Xu M, Huang Y, Zhou Y, Johnson DM, Tu Z (2019) Color-induced changes in oxygen consumption and swimming performance of juvenile bighead carp (Aristichthys nobilis). Fish Physiol Biochem 45:1771-1777

Submitted: November 5, 2019; Accepted: February 3, 2020 Proofs received from author(s): March 24, 2020 